\title{
ВИЗНАЧЕННЯ РЕСУРСУ АКСІАЛЬНО-ПОРШНЕВИХ НАСОСІВ ГІДРОПРИВОДІВ БУДІВЕЛЬНИХ МАШИН
}

\author{
Канд. техн. наук Д.В. Онопрейчук, К.І. Мірієв \\ ОПРЕДЕЛЕНИЕ РЕСУРСА АКСИАЛЬНО-ПОРШНЕВЫХ НАСОСОВ ГИДРОПРИВОДОВ \\ СТРОИТЕЛЬНЫХ МАШИН
}

Канд. техн. наук Д.В. Онопрейчук, К.И. Мириев

\section{DEFINING RESOURCES AXIAL PISTON PUMPS FOR HYDRAULIC ACTUATORS BUILDING MASHINRY}

Cand. of techn. sciences D.V. Onopreychuk, K.I. Miriyev

\begin{abstract}
Розглядається математична модель визначення ресурсу аксіально-поршневих насосів 3 урахуванням швидкості зносу плунжерних пар.

Ключові слова: робоча рідина, аксіально-поршневий насос, плунжерні пари, швидкість зносу.
\end{abstract}

Рассматривается математическая модель определения ресурса аксиально-поршневых насосов с учетом скорости износа плунжерных пар.

Ключевые слова: рабочая жидкость, аксиально-поршневой насос, плунжерные пары, скорость износа.

The mathematical model defining resource axial-piston pumps with regard to speed plunger wear. The rate of wear of plunger in turn depends on the working fluid, ie, the time between. Throughout the time where aircraft Surround speed hydraulic plunger pump wear changing. This process involves the gradual contamination of the working fluid, deterioration of surfactants and others. So better to talk about the timeframe in which is possible to achieve volumetric efficiency of the pump its limit. Thus, when calculating the resource must be considered an average value of wear rate plunger axial-piston pumps.

Keywords: fluid, axial-piston pump, plunger pair, velocity wear.

\begin{abstract}
Вступ. Найдорожчими, а також визначаючими працездатність агрегатами машин $є$ аксіально-поршневі насоси (АПН). Підвищення строків їх служби впливає на збільшення ресурсу машини в цілому, що у свою чергу дає можливість економити значні кошти.
\end{abstract}

Важливим фактором, що впливає на ресурс гідроагрегатів, є властивість робочої рідини (РР). Згідно 3 проведеним аналізом наукових робіт у цьому напрямку, саме стан РР (змінюється 3 часом напрацювання) впливає на швидкість зношування плунжерних пар АПН, що у свою чергу визначає строк служби гідроагрегату [1-7]. Саме тому в розрахунках ресурсу АПН гідроприводів будівельних машин необхідно враховувати швидкість зносу.

\begin{abstract}
Метою дослідження $\epsilon$ визначення ресурсу аксіально-поршневого насоса 3 урахуванням швидкості зношування плунжерних пар.
\end{abstract}

Виклад основного матеріалу. Виходячи 3 раніше проведених досліджень [7-9], швидкість зношування плунжерних пар АПН залежить від напрацювання РP, що у свою чергу впливає на інтенсивність падіння коефіцієнта корисної дії (ККД) насоса. ККД є характеристикою стану АПН, і це означає, що закономірність зміни об'ємного ККД насоса в часі можна відобразити за допомогою графіка (рис. 1). Характер кривої зміни ККД у часі був встановлений у раніше проведених дослідженнях $[1,10,11]$. 


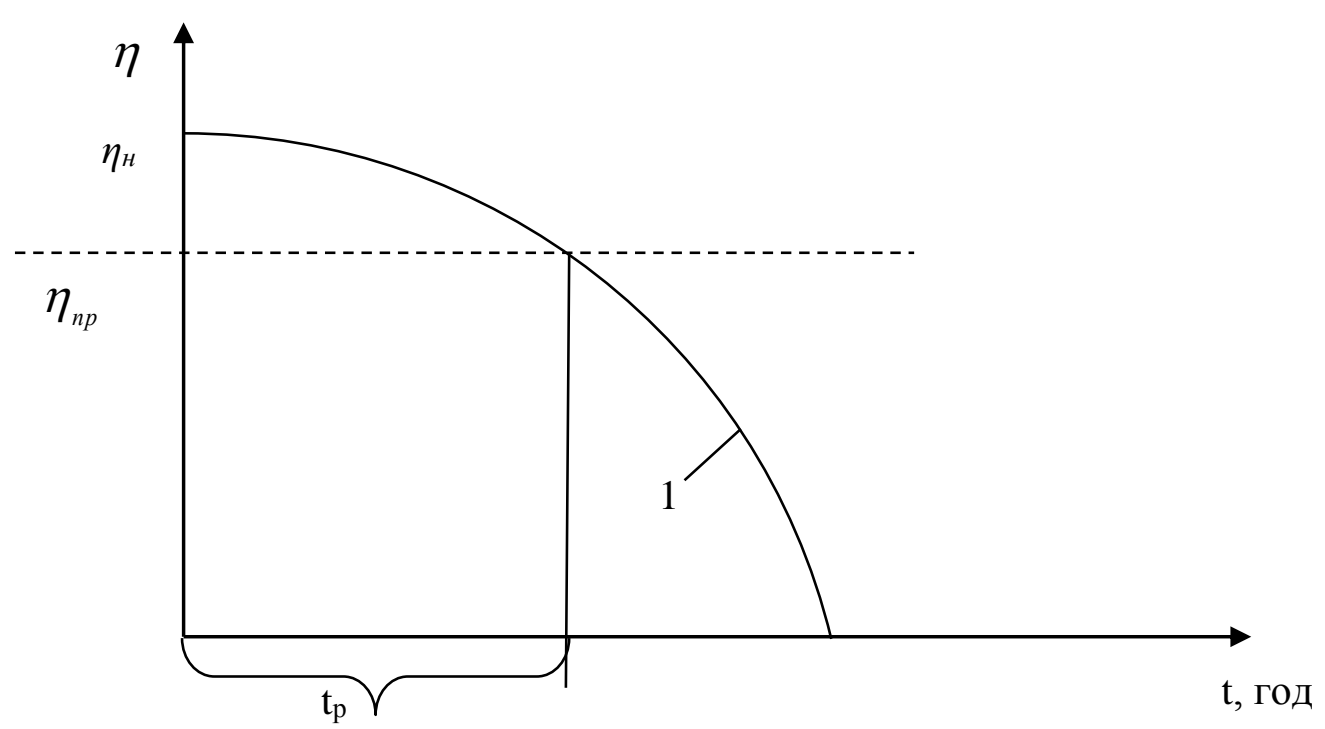

Рис. 1. Зміна ККД насоса в часі:

1 - крива зміни ККД у часі; $\eta_{t}$ - номінальне значення об'ємного ККД; $\eta_{2 p}$ - граничне значення об’ємного ККД; $t_{p}$ - ресурс гідроагрегату

Ресурс надійної роботи гідроагрегату обмежується граничним значенням ККД АПН, що становить $15 \%$ падіння від номінального значення об'ємного ККД насоса. Дані характеристики залежать від швидкості зносу плунжерних пар насоса. При цьому, за умов рівномірного зносу, величина зазору плунжерних пар знаходиться через граничне значення ККД насоса за виразом

$$
\delta_{\tilde{A} D}=\sqrt[3]{\frac{12 \cdot \mu \cdot L_{\ddot{I}} \cdot Q_{0}}{\pi \cdot k_{\hat{a}} \cdot N_{\ddot{I} \ddot{E}} \cdot \Delta p \cdot d_{\ddot{I}}}\left(1-\eta_{\tilde{A} D}\right)} .
$$

де $k_{e}$ - коефіцієнт, що враховує ексцентриситет розташування плунжера відносно осі втулки;

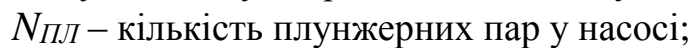

$\Delta p$ - перепад тиску в насосі, $M П a$;

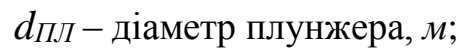

$\mu$ - динамічна в'язкість РР, Па $c$;

$Q_{0}$ - подача насоса при мінімальному тиску в нагнітальній магістралі і номінальній частоті обертання, $л / x в$;

$L_{П Л}$ - середня довжина зазору, що дорівнює половині ходу поршня, $\mathcal{M}$;

$\eta_{\Gamma P}$ - граничне значення коефіцієнта корисної дії насоса.

Величина зазору визначається зносом плунжерної пари, отже, розглянемо схематично плунжерну пару (рис. 2).

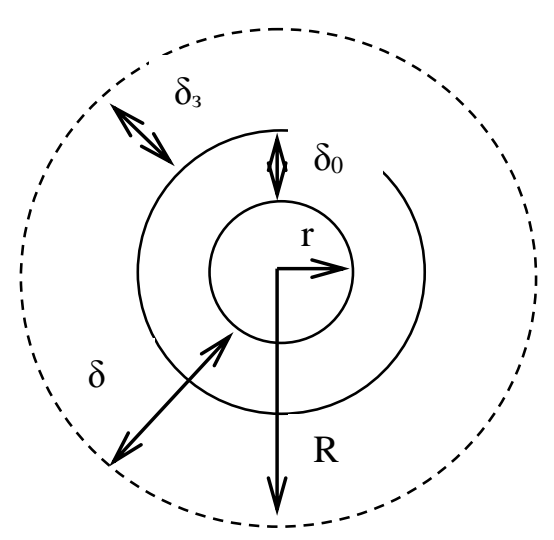

Рис. 2. Схема зносу плунжерної пари: $\mathrm{R}$ - радіус циліндра; $\mathrm{r}$ - радіус плунжера; $\delta_{0}-$ початковий зазор; $\delta$ - загальний зазор 
За рис. 2 $\delta=R-r$. величина зазору

Під час роботи плунжерної пари реалізується контакт поверхонь по площині, а отже, об'єм зношеної поверхні визначатиметься

$$
V_{c}=S_{c} \cdot L_{i \dddot{e}}=\pi\left(R^{2}-\left(r+\delta_{0}\right)^{2}\right) \cdot L_{i \ddot{e}},
$$

де $L_{n л}$ - довжина плунжера.

Звідси

$$
R^{2}-\left(r+\delta_{0}\right)^{2}=\frac{V_{C}}{\pi \cdot L_{i \ddot{ }}} .
$$

Враховуючи те, що перед початком експлуатації в плунжерній парі $\epsilon$ деякий

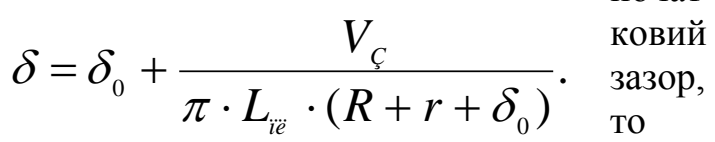

загаль ний зазор з урахуванням зносу набуде вигляду:

Об'єм зношеної поверхні залежить від часу напрацювання плунжерної пари та швидкості зносу поверхонь тертя. Швидкість зносу є функцією часу:

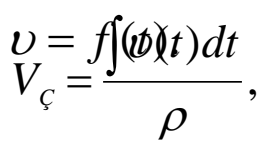
дорівнювати

Отже, об'єм зношеної поверхні буде

де $\rho$ - густина матеріалу, що зношується.

Підставивши вираз (7) у вираз (5) загальний зазор визначатиметься $\frac{\delta=\delta+\frac{\int v(t) d t}{\pi \cdot L_{i e} \cdot\left(R+r+\delta_{0}\right) \cdot \rho}}{\sigma}$ плунжерної пари можна визначити за виразом

Отриманий вираз дає змогу прогнозувати величину зазору плунжерних пар 3 урахуванням швидкості їх зношування.

Оскільки ресурс насоса визначається граничним значенням його ККД, то доцільним $\epsilon$ визначення граничного зносу, який, враховуючи вирази (2), (3), (4), (5), (7), матиме вигляд:

$$
I_{\tilde{A} D}=L_{\ddot{I} \mathscr{E}} \cdot \pi\left(\left(\delta_{\tilde{A} D}+r\right)^{2}-\left(r+\delta_{0}\right)^{2}\right) \cdot \rho .
$$

Знос є функцією об’ємного ККД насоса, а отже, ресурс гідроагрегату до настання $\eta Г Р$ можна визначити виразом

$$
t_{ð}=\frac{I_{\tilde{A} D}}{v} .
$$

Протягом усього часу експлуатації техніки 3 об'ємним гідроприводом швидкість зношування плунжерних пар насоса змінюється. Цей процес пов'язаний 3 поступовим забрудненням РР, спрацюванням поверхнево-активних речовин (ПАР) та ін. Тому доцільніше говорити про діапазон часу, в якому можливе досягнення об'ємного ККД насоса свого граничного значення. Отже, при розрахунку ресурсу необхідно враховувати середнє значення швидкості зношування плунжерних пар АПН:

$$
t_{\delta}=\frac{I_{\tilde{A} \oplus}}{v_{\tilde{N} D} \pm \sigma_{V_{C i}}},
$$

де $v_{C P}$ - середня швидкість зносу плунжерної пари;

$\sigma_{V з н}-$ середнє квадратичне відхилення швидкості зношування.

Зв'язок швидкості зношування від часу напрацювання РP встановлено в експериментальних дослідженнях [8-10]. 


\section{Підйомно-транспортні, дорожні, будівельні, меліоративні машини і обладнання}

\begin{tabular}{llll}
\hline \hline Висновок. & Розроблена & математична & плунжерних пар, яка залежить від \\
модель розрахунку ресурсу & аксіально- & напрацювання робочої рідини та матеріалу 3 \\
поршневих насосів гідроприводів будівельних & яких виготовлені поверхні тертя. \\
машин, що враховує швидкість зносу &
\end{tabular}

\section{Список використаних джерел}

1. Руднев, В.К. Повышение эксплуатационной надежности гидроприводов строительных и дорожных машин [Текст]: учеб. пособие / В.К. Руднев, Е.Н. Лысиков, Е.С. Венцель. - К.:УМК ВО, 1989. - $136 \mathrm{c}$.

2. Руднев, В.К. Эксплуатационные материалы для строительных и дорожных машин [Текст]: учеб. пособие / В.К. Руднев, Е.С. Венцель, Е.Н. Лысиков. - К.: ИСИО, 1993. - 236 с.

3. Руднев, В.К. Повышение ресурса гидроагрегатов строительных и дорожных машин [Текст]: учеб. пособие / В.К. Руднев, К.В. Руднев. - Орел: ОрелГТУ, 2001. - 184 с.

4. Повышение ресурса технических систем путём использования электрических и магнитных полей [Текст] / Е.Е. Александров, И.А. Кравец, Е.Н. Лысиков [и др.]. - Харьков: НТУ «ХПИ», 2006. 544 c.

5. Лысиков, Е.Н. Надмолекулярные структуры жидких смазочных сред и их влияние на износ технических систем [Текст] / Е.Н. Лысиков, В.Б. Косолапов, С.В. Воронин. - Харьков: ЭДЭНА, 2009 $274 \mathrm{c}$.

6. Косолапов, В.Б. Повышение эксплуатационной надежности гидроприводов строительных и дорожных машин при воздействии внешнего электрического поля на рабочую жидкость [Текст]: дис. ... канд. техн. наук / В.Б. Косолапов. - Харьков, 1995. - 212 с.

7. Никитин, Г.А. Влияние загрязненности жидкости на надежность работы гидросистем летательных аппаратов [Текст] / Г.А. Никитин, С.В. Чирков. - М.: Транспорт, 1969. - 183 с.

8. Лисіков, С.М. Швидкість зносу спряжень в гідроприводах технічних систем при обробці робочої рідини електростатичним полем [Текст] / С.М. Лисіков, Д.В. Онопрейчук // Механіка i машинобудування. - 2010. - № 1. - С. 171-176.

9. Лысиков, Е.Н. Влияние электростатической обработки рабочих жидкостей на интенсивность износа пар трения гидроприводов [Текст] / Е.Н. Лысиков // Вестник ХГАДТУ. - Харьков: ХГАДТУ, 2000. - Вып. 12-13.

10. Лисіков, Є.М. Підвищення темпу інженерних робіт при виконанні службово-бойових завдань ВВ МВС України шляхом модернізації гідроприводу машин інженерного озброєння [Текст] / Є.М. Лисіков, Д.В. Онопрейчук // 3б. наук. праць. АВВ МВС України. - Харків: АВВ МВС України, 2010. - Вип. 2. - С. 19-22.

11. Лисіков, С.М. Підвищення ККД аксіально-плунжерних насосів шляхом використання впливу електростатичного поля [Текст] / Є.М. Лисіков, Д.В. Онопрейчук // Зб. наук. праць. АВВ МВС України. - Харків: АВВ МВС України, 2011. - Вип. 1(17). - С. 105-109.

Рецензент д-р техн. наук, професор М.П. Ремарчук

Онопрейчук Дмитро В'ячеславович, канд. техн. наук, асистент кафедри будівельних, колійних та вантажнорозвантажувальних машин Української державної академії залізничного транспорту. Тел.: 057-730-10-72. Мірієв Каміл Істмат, магістрант групи МЗ-БКМ-Б-12 Української державної академії залізничного транспорту.

Onopreychuk Dmytro, kand. tekhn. sciences, assistant of department of build, travel and freight-unloading machines. Ukrainian state academy of railway transport.

Miriyev Kamil, master's degree of group MZ-BKM-B-12, Ukrainian state academy of railway transport. 